Vol 1, No 3, November 2020: 152-158, DOI: $10.34007 /$ ins.v1i3.27

\title{
GAMBARAN PENYAKIT DEMAM BERDARAH DENGUE DI RUMAH SAKIT UMUM LUBUK PAKAM
}

\section{DESCRIPTION OF DENGUE HEMORRHAGIC FEVER AT PAKAM HOLIDAY'S GENERAL HOSPITAL}

\author{
Yessi Sundari \\ Staff Rumah Sakit Umum Lubuk Pakam, Deli Serdang, Indonesia \\ Diterima: 20 Maret 2021; Disetujui: 30 Maret 2021; Dipublish: 31 Maret 2021 \\ *Coresponding Email: yessisundari@gmail.com
}

\begin{abstract}
Abstrak
DBD (Demam Berdarah Dengue) merupakan suatu penyakit yang disebabkan virus dengue yang menular melalui gigitan nyamuk dan menurunkan jumlah trombosit pada penderitanya. Penelitian ini bertujuan untuk mengetahui rekam medis penyakit demam berdarah dengue di Rumah Sakit Umum Lubuk Pakam. Jenis penelitian yang dilakukan adalah deskriptif. Metode pengumpulan data secara rekam medis seluruh penderita DBD dari tahun 2005 s.d 2009 di Rumah Sakit Umum Lubuk Pakam. Kemudian data rekam medis tersebut dikelompokkan berdasarkan usia, jenis kelamin dan pekerjaan. Berdasarkan hasil penelitian diperoleh bahwa jumlah penderita DBD pada tahun 2005 s.d 2009 meningkat pada kelompok usia 21-56 tahun dengan jenis kelamin semuanya laki-laki dan pekerjaan sebagai wiraswasta. Hal ini disebabkan lingkungan yang semakin sempit, jumlah penduduk semakin bertambah, dan tempat tinggal yang sudah tidak memadai dengan tidak adanya ventilasi udara yang baik, sehingga penyebaran penyakit DBD menjadi semakin meningkat.
\end{abstract}

Kata kunci : DBD (Demam Berdarah Dengue); Rekam medis; Lubuk Pakam

\begin{abstract}
$D B D$ is a disease caused by the dengue virus which is transmitted through mosquito bites and reduces the platelet count in the sufferer. This study aims to determine the medical records of dengue hemorrhagic fever at Lubuk Pakam General Hospital. This type of research is descriptive. Data collection methods were medical records for all DHF patients from 2005 to 2009 at Lubuk Pakam General Hospital. Then the medical record data are grouped by age, sex and occupation. Based on the results of the study, it was found that the number of DHF sufferers from 2005 to 2009 increased in the 21-56 year age group with all male sex and work as entrepreneurs. This is due to a narrower environment, increasing population, and inadequate living quarters with no good air ventilation, so that the spread of dengue is increasing.
\end{abstract}

Keywords: DBD; Medical records; Lubuk Pakam

How to Cite: Sundari, Y. (2020). Gambaran Penyakit Demam Berdarah Dengue Di Rumah Sakit Umum Lubuk Pakam. Journal of Natural Sciences.Vol 1 (2): 152-158. 


\section{PENDAHULUAN}

Di negara-negara wilayah tropis, Demam Berdarah Dengue (DBD) umumnya meningkat pada musim penghujan di mana banyak terdapat genangan air bersih yang menjadi tempat berkembang biak nyamuk Aedes aegypty. Di perkotaan, wabah demam berdarah kembali meningkat di awal musim kemarau (Suroso \& Umar, 2000; Yuslina dkk, 2016).

Daerah yang terkena DBD cenderung perkotaan/daerah padat. Rumah-rumah yang berdekatan berperan penting dalam penularan penyakit ini, mengingat nyamuk Aedes aegypty tidak dapat terbang lebih dari $100 \mathrm{~m}$. Koneksi transportasi yang baik antar wilayah memudahkan penyebaran penyakit ini ke wilayah lain. Karena wilayah dengan jumlah penduduk yang meningkat dan transportasi yang lebih baik serta perilaku masyarakat dalam penyimpanan air di Indonesia sangat rawan berkembangnya jentik nyamuk Aedes aegypti dan virus Dengue, masalah penyakit DBD akan semakin besar jika tidak dilakukan upaya pemberantasan yang intensif. Pencegahan berkembangnya nyamuk Aedes aegypti sebagai penular DBD sangatlah penting (Nadesul, 2004; Yudhastuti \& Vidiyani, 2005).

Dalam upaya pengendalian wabah DBD, dibandingkan negara lainnya di Asia Tenggara, Indonesia termasuk salah satu negara yang masih mengalami masalah. Indonesia memang sangat jauh tertinggal bila dibandingkan Singapura, yang sejak awal 1980-an dapat dikatakan telah berhasil memberantas wabah penyakit DBD (Ooi, 2001). Penanganan secara cepat wabah penyakit DBD di Indonesia setiap tahunnya selalu menjadi masalah karena pemerintah dinilai oleh masyarakat lamban menanganinya. Obat dan vaksin DBD sampai saat ini belum tersedia. Pengobatan yang dilakukan hanya untuk mengurangi gejala sakit dan mengurangi risiko kematian (Permatasari dkk, 2013).

Penanggulangan DBD secara umum ditujukan pada pemberantasan rantai penularan dengan memusnahkan pembawa virusnya (vektornya) yaitu nyamuk Aedes aegypty dengan memberantas sarang per kembangbiakannya yang umumnya ada di air bersih yang tergenang di permukaan tanah maupun di tempattempat penampungan air (Nadesul, 2004; Sudarmaja \& Mardihusodo, 2009). Kajian spesifik tentang kebijakan pencegahan dan penanggulangan DBD ini diharapkan dapat memberi sumbangan kepada kajian kebijakan pemberantasan wabah penyakit secara umum yang telah diberlakukan di Indonesia (Depkes, 2005). 
Sejak pertama kali ditemukan jumlah kasus menunjukkan kecenderungan meningkat baik dalam jumlah maupun luas wilayah yang terjangkit dan secara sporodis selalu terjadi KLB setiap tahun. Berdasarkan data yang didapatkan jumlah penderita DBD dari 1 Januari s.d 10 Agustus 2005 di seluruh Indonesia mencapai 38.635 orang, sebanyak 539 penderita diantaranya meninggal dunia. Oleh karena itu diperlukan data mengenai penderita penyakit DBD di daerah berdasarkan rekam medis terutama di Rumah Sakit Umum Lubuk Pakam.

\section{METODE PENELITIAN}

Penelitian ini dilaksanakan pada bulan Januari s.d Maret 2010 di Rumah Sakit Umum Lubuk Pakam. Jenis penelitian ini dengan menggunakan pengumpulan data penderita DBD dari tahun 2005 - 2009 di Rumah Sakit Umum Daerah Deli Serdang Lubuk Pakam. Sampel pada penelitian ini adalah pasien yang terjangkit DBD dari tahun 2005-2009 yang berjumlah 1109 orang. Hasil rekam medis yang diambil berdasarkan 3 kategori yaitu, usia, jenis kelamin, dan jenis pekerjaan. Pasien penderita dikelompokkan menjadi 5 kelompok berdasarkan usia, yaitu : 1) Balita (0-5 tahun); 2)Anak-anak (6-14 tahun); 3)Remaja (15-20 tahun); 4)Dewasa (21-56 tahun); dan 5)Lansia (57 tahun keatas). Data diperoleh dari seluruh pasien yang datang berobat ke Rumah Sakit Umum Lubuk Pakam.

\section{HASIL DAN PEMBAHASAN}

Berdasarkan hasil rekam medis yang telah dilakukan di RSUD Deli Serdang Lubuk Pakam tahun 2005-2009 dikumpulkan dan diolah, maka didapat data yang disajikan dalam bentuk diagram yang menghasilkan gambaran kejadian penyakit Demam Berdarah Dengue (DBD) di Rumah Sakit Umum Daerah Deli Serdang Lubuk Pakam Tahun 2005 - 2009. Sesuai dengan data maka hasil penelitian ini dibagi dalam tiga kategori yaitu :

1. Penderita DBD berdasarkan kelompok umur 
Tabel 1. Jumlah Penderita DBD (orang) berdasarkan kelompok usia di tahun 20052009

\begin{tabular}{llcccccc}
\hline \multirow{2}{*}{ No } & \multirow{2}{*}{ Usia (thn) } & $\mathbf{2 0 0 5}$ & $\mathbf{2 0 0 6}$ & $\mathbf{2 0 0 7}$ & $\mathbf{2 0 0 8}$ & $\mathbf{2 0 0 9}$ & \multirow{2}{*}{ Jumlah } \\
\hline 1 & $0-5$ & 15 & 27 & 14 & 12 & 36 & 104 \\
2 & $6-14$ & 32 & 35 & 29 & 51 & 79 & 226 \\
3 & $15-20$ & 12 & 25 & 223 & 28 & 31 & 119 \\
4 & $21-56$ & 73 & 129 & 78 & 136 & 148 & 564 \\
5 & $57>$ & 2 & 30 & 20 & 22 & 22 & 96 \\
\hline & Jumlah & $\mathbf{1 3 4}$ & $\mathbf{2 4 6}$ & $\mathbf{1 6 4}$ & $\mathbf{2 4 9}$ & $\mathbf{3 1 6}$ & $\mathbf{1 1 0 9}$ \\
\hline
\end{tabular}

Dari Tabel 1 di atas menunjukkan bahwa jumlah penderita DBD dari tahun 2005-2009 terdapat peningkatan dan penurunan, dimana terjadi peningkatan yang signifikan pada tahun 2009 yaitu bertambah 24 orang dibanding tahun 2008. Hal ini terjadi karena jumlah penduduk yang semakin bertambah dan lingkungan tempat tinggal yang semakin sempit sehingga memungkinkan penyebaran virus DBD ini semakin besar. Bagi balita yang daya tahan tubuhnya masih lebih rentan maka hal tersebut menjadi salah satu faktor terkena DBD.

Pada kelompok anak-anak (6-14 tahun) jumlah penderita DBD sebanyak 226 orang dengan perincian pada tahun 2005 sebanyak 32 orang, tahun 2006 sebanyak 35 orang, tahun 2007 sebanyak 29 orang, tahun 2008 sebanyak 51 orang dan pada tahun 2009 dijumpai penderita sebanyak 79 orang. Jumlah penderita DBD pada kelompok ini bertambah tinggi pada tahun 2009 yang disebabkan karena selain musim penghujan juga karena pada usia seperti inilah anak-anak tidak dapat dikontrol saat bermain. Tanpa dapat dihindari anak-anak akan bermain di lingkungan mana saja tanpa mengerti tentang terjadinya penyebaran virus DBD tersebut.

Kelompok remaja (15-20 tahun) jumlah penderita DBD sebanyak 119 orang dengan perincian yaitu pada tahun 2005 sebanyak 12 orang, pada tahun 2006 sebanyak 25 orang, pada tahun 2007 sebanyak 23 orang, tahun 2008 sebanyak 28 orang dan tahun 2009 sebanyak 31 orang. Pada kelompok ini tampak bahwa walaupun terjadi kenaikan penderita dari tahun ke tahun tetapi tidak signifikan karena pada umur ini para remaja sudah mengerti tentang penyakit DBD dan juga cara-cara penularannya sehingga mereka sudah tahu mengantisipasi yaitu dengan menjaga kebersihan lingkungan salah satunya. Selain itu pada umur ini juga lebih mudah dijelaskan tentang penularan penyakit DBD ini sehingga para remaja ini lebih mudah mengerti untuk menghindari faktor-faktor yang membuat penyakit DBD ini cepat menyebar. 
Kelompok dewasa (21-56 tahun) jumlah penderita DBD dengan perincian yaitu pada tahun 2005 sebanyak 73 orang, tahun 2006 sebanyak 129 orang, tahun 2007 sebanyak 78 orang, tahun 2008 sebanyak 136 orang dan pada tahun 2009 sebanyak 148 orang. Pada kelompok ini jumlah penderita lebih banyak pada tahun 2009 karena jumlah penduduk Lubuk Pakam lebih banyak yang dewasa menurut data statistik kependudukan Lubuk Pakam tahun 2010, sehingga kemungkinan yang lebih banyak terjangkit virus ini adalah kelompok dewasa.

Pada kelompok lansia ( $>57$ tahun) jumlah penderita DBD sebanyak 96 orang dengan perincian yaitu pada tahun 2005 sebanyak 2 orang, tahun 2006 sebanyak 30 orang, tahun 2007 sebanyak 20 orang, tahun 2008 sebanyak 22 orang dan pada tahun 2009 sebanyak dijumpai penderita dengan jumlah yang sama yaitu 22 orang. Pada tahun 2005 dijumpai penderita DBD sebanyak 2 orang pada kelompok lansia karena keinginan untuk datang berobat ke Rumah Sakit sangat kecil dan mereka pada umumnya lebih memilih pengobatan kampung dan mereka merasa tidak begitu penting karena usia yang sudah lanjut sehingga data yang diperoleh tidak objektif. Jumlah penderita DBD pada semua jenis kelompok umur dari tahun 2005-2009 terjadi kenaikan yang disebabkan lingkungan yang semakin sempit, jumlah penduduk makin bertambah dari tahun ke tahun dan tempat tinggal yang tidak memadai yaitu semakin rapat bahkan ada rumah yang tidak memakai ventilasi udara yang baik. Hal ini membuat penyebaran virus DBD melalui gigitan nyamuk menjadi semakin tinggi lagi.

2. Penderita DBD Berdasarkan Jenis Kelamin

Tabel 2. Jumlah Penderita DBD Berdasarkan Jenis Kelamin pada Tahun 2005-2009

\begin{tabular}{cccccccc}
\hline \multirow{2}{*}{ No } & $\begin{array}{c}\text { Jenis } \\
\text { Kelamin }\end{array}$ & $\mathbf{2 0 0 5}$ & $\mathbf{2 0 0 6}$ & $\mathbf{2 0 0 7}$ & $\mathbf{2 0 0 8}$ & $\mathbf{2 0 0 9}$ & \multirow{2}{*}{ Jumlah } \\
\hline 1 & Laki-Laki & 74 & 141 & 82 & 135 & 149 & 581 \\
2 & Perempuan & 60 & 105 & 82 & 114 & 167 & 528 \\
\hline & Jumlah & $\mathbf{1 3 4}$ & $\mathbf{2 4 6}$ & $\mathbf{1 6 4}$ & $\mathbf{2 4 9}$ & $\mathbf{3 1 6}$ & $\mathbf{1 1 0 9}$ \\
\hline
\end{tabular}

Berdasarkan Tabel 2, menunjukkan bahwa Penderita DBD lebih banyak dialami Laki-laki karena yang lebih banyak beraktifitas di luar rumah dan laki-laki lebih kurang menjaga dan memperhatikan kebersihan dibanding perempuan sehingga memungkinkan penyebaran virus DBD dari orang yang sudah terjangkit virus 
tersebut. Menurut survey data statistik daerah Deli Serdang tahun 2005-2009 juga menunjukkan jumlah penderita laki- laki lebih banyak dibanding perempuan.

3. Penderita DBD Berdasarkan Pekerjaan

Tabel 3. Jumlah Penderita DBD Berdasarkan Jenis Pekerjaan pada Tahun 2005-2009

\begin{tabular}{llcccccc}
\hline No & $\begin{array}{c}\text { Jenis } \\
\text { Pekerjaan }\end{array}$ & $\mathbf{2 0 0 5}$ & $\mathbf{2 0 0 6}$ & $\mathbf{2 0 0 7}$ & $\mathbf{2 0 0 8}$ & $\mathbf{2 0 0 9}$ & Jumlah \\
\hline 1 & PNS & 22 & 30 & 16 & 35 & 39 & 142 \\
2 & Peg. Swasta & 12 & 17 & 13 & 19 & 19 & 80 \\
3 & Nelayan & 19 & 22 & 14 & 28 & 28 & 111 \\
4 & Wiraswasta & 35 & 120 & 83 & 124 & 144 & 506 \\
5 & Petani & 34 & 57 & 34 & 38 & 58 & 221 \\
6 & Supir & 4 & - & - & - & 10 & 14 \\
7 & Buruh & 2 & - & 1 & 1 & 8 & 12 \\
8 & Tkg Becak & 2 & - & - & - & 1 & 3 \\
9 & Lain-lain & 4 & - & 3 & 4 & 9 & 20 \\
\hline & Jumlah & 134 & 246 & 164 & 249 & 316 & 1109 \\
\hline
\end{tabular}

Tabel 3 menunjukkan bahwa Penderita DBD lebih banyak dijumpai pada pekerjaan wiraswasta lebih banyak karena mayoritas penduduk Deli Serdang berprofesi sebagai wiraswasta yang lebih sering bertugas sampai kedaerah-daerah lain bahkan yang terpencil sekalipun. Penderita DBD dengan pekerjaan sebagai tukang Becak sebanyak 3 orang karena penduduk Deli Serdang tidak banyak yang bekerja sebagai tk. Becak dan penduduk yang berprofesi sebagai tukang Becak ini tidak begitu peduli dengan pengobatan, sehingga apabila ada masalah kesehatan yang ditandai dengan demam, mereka lebih memilih pengobatan alternatif ataupun berobat kampung dan malas untuk datang ke Rumah Sakit untuk melakukan pengobatan karena adanya prinsip bahwa biaya berobat ke Rumah Sakit adalah mahal.

Berdasarkan 3 kriteria yang diamati bahwa penderita DBD pada tahun 2005 sebanyak 134 orang, tahun 2006 sebanyak 246 orang, tahun 2007 sebanyak 164 orang, tahun 2008 sebanyak 249 orang dan tahun 2009 sebanyak 316 orang. Penyakit DBD ini cenderung meningkat karena sikap masyarakat setempat yang tidak peduli menjaga kebersihan lingkungan, kesadaran dalam menjalankan program pemerintah yang dikenal dengan $3 \mathrm{M}$ yaitu menutup tempat penampungan air, menguras bak air dan mengubur kaleng bekas masih sangat kurang peran sertanya. 
Menurut Kustriastuti (2009) Indonesia mempunyai dua musim yaitu musim penghujan dan musim kemarau sangat mendukung penyebaran virus DBD ini dimana peningkatan penyakit DBD ini lebih tinggi saat musim penghujan dibanding musim kemarau. Menurut Chandra (2010) Selain itu penyebaran penyakit DBD ini juga didukung oleh rumah penduduk yang sangat rapat, kurangnya ventilasi sehingga pertukaran udara yang tidak sempurna. Jumlah penduduk yang semakin bertambah maka limbah atau sampah hasil penduduk pun akan bertambah juga dimana bila pengelolahan limbah tersebut tidak baik maka hal tersebut juga merupakan salah satu faktor tempat berkembang biak nya vector nyamuk Aedes aegypti.

\section{SIMPULAN}

Hasil rekam medis penyakit Demam Berdarah Dengue (DBD) di Rumah Sakit Umum Lubuk Pakam dapat disimpulkan bahwa jumlah penderita DBD pada tahun 2005 berjumlah 134 orang, tahun 2006 berjumlah 246, tahun 2007 berjumlah 164, tahun 2008 berjumlah 249, dan pada tahun 2009 meningkat menjadi 316 orang. Hal ini dipengaruhi oleh semakin padatnya penduduk dan kurangnya perhatian terhadap kebersihan lingkungan sekitar. Berdasarkan 3 kategori yang diamati dalam hasil rekam medis bahwa dari tahun 2005-2009 meningkat pada pasien berusia 21-56 tahun, jenis kelamin laki-laki dan bekerja sebagai wiraswasta.

\section{DAFTAR PUSTAKA}

Candra, A. (2010). Demam Berdarah Dengue: Epidemiologi, Patogenesis, dan Faktor Risiko Penularan. Aspirator Journal of Vector-Borne Diseases, 2(2), 53636.

Depkes. (2005). Demam Berdarah Dengue : Kasus Luar Biasa. Jakarta : Gramedia Pustaka Umum.

Nadesul. (2004). DBD : Pencegahan dan Pengobatan. Jakarta : Bakti

Ooi. (2001). Wabah Demam Berdarah Dengue. Singapura

Permatasari, D. Y., Ramaningrum, G., \& Novitasari, A. (2013). Hubungan status Gizi, umur, dan jenis kelamin dengan derajat infeksi dengue pada anak. Jurnal Kedokteran Muhammadiyah, 2(1).

Sudarmaja, I. M., \& Mardihusodo, S. J. (2009). Pemilihan tempat bertelur nyamuk Aedes aegypti pada air limbah rumah tangga di Laboratorium. Jurnal Veteriner, 10(4), 205-207.

Yudhastuti, R., \& Vidiyani, A. (2005). Hubungan kondisi lingkungan, kontainer, dan perilaku masyarakat dengan keberadaan jentik nyamuk Aedes aegypti di daerah endemis demam berdarah dengue Surabaya. Jurnal Kesehatan Lingkungan, 1(2).

Yuslina, H., Kardhinata, E.H., Sartini., (2016), Gambaran Penyakit Demam Berdasarkan Umur dan Jenis Kelamin Pasien Rumah Sakit Haji Medan, BioLink, Vol. 2 (2), Hal: 118-125 